\title{
THE AESTHETIC THEORY
}

\section{OF GABRIEL MARCEL}

\begin{abstract}
Coming home the other evening from an excellent Bach concert, I thought to myself, "Here is something that restores to one a feeling that one might have thought lost, or perhaps something more than a feeling, an assurance: the assurance that it is an honour to be a man." It is important to notice that everything seems to be in alliance to-day to destroy this notion of human honour... What sort if a thing is this "honour" of which the awareness was awakened in me the other night after hearing a few concertos by Bach?...In one sense, no music is more satisfying to the reason than that of Bach, but on the other hand that satisfaction soon transcends itself to become a higher state...Reason,. ${ }^{1}$
\end{abstract}

With this passage from Man Against Mass Society, Marcel exposes the unique power of aesthetic experience.

1 Gabriel Marcel, Man Against Mass Society, trans by G.S. Frasier, (Chicago: Regnery: 1952), 249-50, 253; "En rentrant chez moi l'autre soir, après avoir écouté un admirable concert de Bach, je songeais: voilà qui nous restitue un sentiment qu'on pourrait croire perdu, plus qu'un sentiment peut-être, une assurance: l'honneur d'être un homme. Il est important de remarquer que tout semble se coaliser aujourd'hui pour ruiner cette notion...Qu'est-ce que cet honneur dont la conscience se réveillait en moi l'autre soir à l'audition de quelques concertos de Bach?...En un certain sens, il n'y a pas de musique plus satisfaisante pour la raison que celle de Bach, mais il est d'autre part manifeste que cette satisfaction, qui bien vite se dépasse pour devenir exaltation...La raison qui se reconnait comblée par la musique de Bach se dilate, au contraire, pour accueillir cette lumière-là n'est pas d'une autre essence qu'ellemême" [Gabriel Marcel, Les Hommes contre L'humain, (Paris: Editions Universitaires, 1991), 153,191]. 
Aesthetics bears moral and ontological implications. Within the context of Marcellian thought, aesthetics plays a crucial role. Aesthetics opens access to the particular and it is only by a rediscovery of the worth of the particular that being can be viewed as full. Beauty feeds and fructifies reason and morality. To paraphrase Plato, the true hides behind the beautiful. Aesthetic experience was especially dear to Marcel. He understood that drama, music and art had the power to make his philosophy concrete, to augment his philosophy by their compensatory otherness: "He [Marcel] wrote his first two plays at the age of eight, and from then on the theatre, because of its 'significant bearing on other existences,' never lost its fascination for him."2 Marcel, being a playwright, a classical composer and concert pianist, credits drama and music with providing the impetus which drives his philosophical thought. On the one hand, music, especially the work of Mozart and Beethoven, enkindled in him the urge to transcend. Marcel credits music repeatedly: "A musical phrase by Bach or Beethoven--and here I mean almost exclusively the Beethoven of the last period--seems invested with a supreme authority which did not allow of any explanation. One was beyond knowledge and yet it was as if one breathed a certainty which went infinitely beyond the limits of a simple emotion deriving from a particular temperament or sensitivity."3

${ }^{2}$ Kurt Reinhardt, The Existentialist Revolt, (New York: Ungar Publishing, 1972), 203.

3 Marcel, The Existential Background of Human Dignity, The William James Lectures at Harvard University, 1961-1962, (Cambridge: Harvard University Press, 1963), 26; cf., "Telle phrase de Bach ou de la Beethoven -- je vise ici presque exclusivement le Beethoven de la dernière période -- m'apparaissait comme investie d'une autorité souveraine dont aucune explication quelle qu'elle fût ne permettait de rendre compte. On était donc là au-delà de tout savoir et pourtant c'était comme si on 
On the other hand, his plays ground him in the realm of the concrete and the real such that the tendency towards abstraction would not become violent or reductional. Drama and music served heuristic and disciplinary purposes for Marcel. He wrote some years later: "In drama and by means of drama, metaphysical thought seizes itself and determines itself in the concrete." 4 Writing in 1925 about the role of music in Bergson's thought, Marcel would make an observation which would be perfectly applicable to his own mature thought: "Bergson's philosophy...has always been as greatly concerned as that of Aristotle or Comte with maintaining the absolute specificity of various spiritual domains, or modes of experience, and...always looked with discomfort and distrust upon any attempt to rationalize these modes and replace them with abstract equivalents.",5

This paper will analyze the roots of Marcel's aesthetic theory as found in the Metaphysical Journal and, also, a short work by Marcel entitled My Dramatic Work as Viewed by a Philosopher. Aesthetics is a discourse which serves a shared purpose with religion and value, each discourse supports the insight into being-itself and subtends a substantial basis

respirait une certitude qui débordait infiniment les limites d'une simple émotion individuelle tributaire d'un tempérament ou d'une sensibilité particulière" [Marcel, la dignité humaine, 44-45].

4 Gabriel Marcel, Positions et approches concrètes du mystère ontologique (in Le Monde cassé), (Louvain: E. Nauwelaerts, 1949), 277.

5 Gabriel Marcel, "Bergsonism and Music," edited by Suzanne K, Langer in Reflection on Art, (Baltimore: the Johns Hopkins Press, 1975), 142-143; cf., "une philosophie qui a toujours eu le souci de maintenir aussi fortement que celles d'Aristotle ou de Comte la spécificité absolue des divers domaines spirituels, ou, si l'on veut, des modes d'expérience, et qui ne considère pas sans inquiètude, sans défiance, les tentatives qui ont pour objet de rationaliser ces modes, des leur substituer des équivalents abstraits" [Marcel, "Bergsonisme et musique," Presense, 2-3, 33]. 
beneath phenomena; each refers to that which is radiant and filled with light for the human person. For Marcel, the aesthetic discourse is something more. In the play between the concreteness of drama and the abstractions of music, one gets a perfect picture of the tension which underlies Marcel's thought. By an investigation of this tension, one is able to attain the deepest insight into Gabriel Marcel as a man and a philosopher.

\section{Aesthetics in the Metaphysical Journal}

Marcel's philosophy is permeated by a deep aesthetic sensitivity. So much so that Marcel will claim his philosophical works are not comprehensible without taking into account the data of his artistic creations, especially his plays. Aesthetics do not serve a purely auxiliary function in the thought of Marcel. Marcel is a thinker who thinks in images. For him, the True hides behind the beautiful. As he has repeatedly affirmed, one cannot separate the truth from the fine sense of truth in which it is expressed.

Concreteness and particularity, which are central concerns of Marcel, are revealed in aesthetic experiences, "strictly speaking it is aesthetic communication which makes possible the communication of individualities." The known object is, at least to some degree, created by one's love for it. Knowledge is legitimated when it is knowledge for-someone. Let us take the example of the Bach organ concerto. It is only known as real, is only adequately known, when it is known by

6 Gabriel Marcel, Metaphysical Journal, trans by Bernard Wall, (Chicago: H. Regnery, 1952), 62, henceforth $\underline{\text { MJ }}$ and JM respectively; " $a$ la rigueur dans la création esthétique qui rend la communion des individus possible" [Gabriel Marcel, Journal Métaphysique, (Paris: Gallimard, 1927), 63]. 
someone who invests it with power by knowing it. Assurance underlies justification, just as love underlies knowledge.

Moreover, the aesthetic experience is incomprehensible unless it is in some manner an appeal and response: "The View of Delft of Vermeer and the Thirteenth Quartet of Beethoven cannot be thought of except as responses to a sort of appeal." ${ }^{, 7}$ It is precisely the distinctness or specificity of the response which establishes a truly metaphysical discourse. Doubtless, this seems ironic, that it is specificity and concreteness which reveal the metaphysical. Yet, this is an essential point. The more that we seek to convert aesthetic experience to the rule of a concept, the more we make of it a vapid abstraction and thereby set ourselves at a distance from the moment of ontological revelation. In order for a work of Vermeer or Beethoven to move one, it is necessary that one respond to these works precisely as one would respond to a call. To clarify even the most basic phenomenological issue, such as that of determining the given, we lack a way of thinking (or perhaps speaking) fluid enough to express these realities. In short, we lack musical forms of thinking. The great works of music, and art as well, have the power "to invoke directly a certain communion." 8 By works of art, we participate in reality directly. Participation constitutes a form of universality which in no way violates the individual.

${ }^{7}$ Marcel, Man Against Mass Society, 172; cf., "La Vue de Delft de Ver Meer ou le Treizième Quatuor de Beethoven ne peuvent être pensés que comme de réponses à un certain appel qui d'ailleurs" [Marcel, Les hommes contre l'humain, 106].

${ }^{8}$ Marcel, Existential Background, 26; cf., "un certain 'nous-tous' que l'cuvre musicale la plus haute semblait atteindre directement" [Marcel, la dignité humaine, 45]. 
The human person, most clearly in the example of music, knows as a participant and not as a mere spectator. Suppose one is present at a musical improvisation and one recognizes the improvisation as such. The recognition which occurs in the case of the improvisation is already a kind of participation; that is, it can only take place if I am somehow "on the inside." Any musician recognizes the truth of this statement. One may simply hear a work of music in a spectator-like fashion. Such a shallow hearing impoverishes the possibility of meaning. An animal hears in such a fashion and possibly is even moved by the hearing, at least, to the extent of being soothed or agitated. A computer might be programmed to copy every note of the improvisation on to its hard drive and play it back without error. Nonetheless, neither dog nor computer grasp the core of the improvisation. Such a "grasping" is only possible for one who can participate in the music from within itself.

"But we can go a step further. It is not inconceivable that the participation contributes in some way to the improvisation itself." ${ }^{10}$ In the aesthetic experience, as in the religious and the ethical, the antagonistic opposition of knower and known is cast down. A fundamental issue is at stake here. The musical improvisation can only be known from within its own reality. There is no privileged, disinterestedly scientific way to understand the improvisation. As has already be shown, any utterly non-involved description (e.g., the

9 Gabriel Marcel, Being and Having, An Existentialist Diary, trans by Katherine Farrer, (New York: Harper and Row, 1965), 16-17; "c'est-à-dire qu'elle ne peut se produire que si en quelque façon je suis à l'intérieur' [Gabriel Marcel, Être et avoir, (Paris: Editions Universitaires, 1991), 19].

10 Marcel, Being and Having, 17; “Mais nous pouvons faire un pas de plus. Il n'est pas inconcevable que cette participation contribue en quelque sorte à l'improvisation elle-même" [Marcel, Être et avoir, 19]. 
computer reduction to a series of musical notes), no matter how exact, fails to grasp the meaning of the improvisation. This is also the case in the area of philosophical knowledge. Philosophy is more a matter of meditation or contemplation, and less a matter of calculation.

Genuine art always has this metaphysical aura surrounding it: "In this sense genuine art is a revelation." Art provides a physical basis which underlies meaning, in that a work of art is fundamentally unable to explain itself and therefore is freed of all causal determinations. The particular, perhaps for the first time in the history of Western thought is, in the work of Marcel raised to the level of an ontological and metaphysical cipher to being. The concrete particular transcends the chain of causal determinations. In other words, once the question of "what a work of art is" presents itself as a question, seeking an answer, fully explaining the work in some causal or deterministic way, the discussion metathesises like a cancer and meaning withers. What is the Toccata and Fugue in D minor by Bach? Or, what is the David by Michelangelo? The first is a series of determinable notes and the second is a particular configuration of marble. However, when one considers these works as art, neither of these descriptions is in any way adequate. To set the problem of the nature of a work of art in such terms is to create a problem which is insoluble and "as impossible as that of squaring the circle." The work of art helps to "throw light on what is too abstract in a theory." The work of art drags human attention back down to the level of the particular.

${ }^{11}$ Marcel, MJ, 79; "En ce sens l'art véritable est une révélation “ [Marcel, JM, 79].

12 Marcel, $\underline{\mathrm{MJ}}, 122$; cf., "L'exemple de l'cuvre d'art permet ici encore d'éclairer ce que la théorie peut en soi avoir de trop abstrait" [Marcel, $\underline{\mathrm{JM}}, 121]$. 
However, the problem with any work of art is: "the more I love it the less I can qualify it, the less the qualification appears adequate for what I experience." 13 It would be relatively easy for me to describe by qualifications the major chromatic scale that I practiced as a child. I exhaust the scale's meaning for me precisely because its meaning for me is so shallow. It does not reach the low water mark of a revelation. Yet, if one just slightly scrambles that scale, one is left with the shimmering revelation of Scriabin or, if one drops and flattens a few notes here and there, one is left with the plaintive moaning of a blue Gershwin. How did meaning so incontrovertibly arise from so much mechanistic drudgery? The notes of the scale unfold in utter monotony, until, suddenly, inexplicably meaning shines forth.

E.M. Cioran in his "Notes for a Character Sketch" of Marcel captures well the meaning of music for Marcel:

I often listened to great music with him. Everything from Monteverdi to Fauré and the great Russian masters, and I noticed that music uplifted him, projected him into some other sphere and transported him to a level of being inaccessible to philosophy except in some rare moments of insight. Proust, who should always be quoted in matters of experiences that are revelations, thought that if people had not the faculty of speech, music would have been the only means of communication between souls. This is approximately what Marcel maintained,

13 Marcel, MJ, 158; “De même l'œuvre d'art: plus je l'aime et moins je peux la qualifier, moins toute qualification comme telle me paraît adéquate à ce que j'éprouve" [Marcel, $\underline{\mathrm{JM}}, 157]$. 
in speaking of his improvisations, when he admitted that through them he was able to delve into his most intimate inner self; it was in this state that "everything would move as if the border between the lands of the living and the dead were disappearing, as if I were entering a universe in which this distinction, I dare say a quite common one, was nearing total eradication."14

For Marcel, music had an eerie capacity. He claimed that it seemed to transport him to another realm. This is, doubtless, very odd language for a man who could not in any way be portrayed as a dualist. Perhaps a literary example would help to clarify Marcel's meaning. Yeats wrote of hell: "Hell is the place for those who have denied and they find there what they have planted and what they have dug, a lake of spaces and a wood of nothing and they wander there and they drift and never cease wailing for substance." Yeats captures the unrest of the metaphysician: They never cease wailing for

14 Cioran, "Notes for a Character Sketch," 78; cf., "Nous avons souvent écouté de la musique ensemble, de Monteverdi à Fauré et aux grands Russes, et j'ai remarqué qu'elle le projetait dans une autre zone d'être, qu'elle le soulevait à un niveau auquel la philosophie se hisse seulement lorsque, après avoir entrevu quelque extrémité, elle fait appel aux points de suspension...Proust, qu'il faut toujours citer lorsqu'il s'agit d'expériences révélatrices, pensait que si l'homme n'avait pas eu le don de la parole, la musique aurait été le seul mode de communication entre les âmes. C'est à peu près la même chose qu'affirmait Gabriel Marcel lorsque, évoquant ses improvisations, il avouait que grâce à elles, il accédait au plus intime de lui-même, là où 'tout se passait vraiment comme si la frontière entre les vivants et les morts s'effaçait, comme si je pénétrais dans un univers où cette opposition, si j'ose dire usuelle, s'abolissait radicalement" [Cioran, "Potrait d'un philosophe," Gabriel Marcel, Les colloques de la bibliotheque nationale, 308-309]. 
substance. Marcel is one of those unique and rare individuals who hears the cry of alienation through the lake of spaces and the wood of nothing. Yet, he does not shrink back in horror. $\mathrm{He}$ is driven to discover presence, that eternal element which is not gnawed away by criticism or dissolved in dialectics. Music was a sign to him that this presence is. Benjamin Britten, in his War Requiem, quotes the English poet Wilfred Owen:

\section{"Strange friend," I said, "there is no cause to mourn." \\ "None" said the other, "save the undone years, the hopelessness}

whatever hope is yours was my life also.

I went hunting after the wildest beauty in the world."

"To hunt after the wildest beauty in the world," and "to wail for substance." By combining these two notions, a Marcellian aesthetics is intimated. To listen to music is not to do metaphysics. However, to listen to music, to truly listen with the depth and participatory intensity of which a human being is capable, is a sign--a sign that metaphysics is possible. It point of fact, it may very well be that any attempt to instigate a metaphysical discourse which does not account for the soul, is a barren endeavor. Yet, modernity has tended to usurp the central organizing function of the soul and to replace it with the mind. Such a replacement is highly problematic. The soul has been reduced to the mind (Gemüt). Soul has thus, since the time of Kant, been more and taken to mean exclusively "mind" and to lose its more traditional meaning as the seat of all human faculties. Such a transformation explains why modernity has become so obsessed with justifications and oblivious to assurances. 
Marcel is not so much concerned with discovering justifications which pertain to knowledge. Rather, he would discover assurances which underlie justifications of human existence. Marcel's philosophy seeks an intermediate level between universal and particular. This level is illustrated by the aesthetic discourse. Great works of art are situated at this level, "the revelation of a masterpiece cannot be reduced to a state of mere felt satisfaction. This intermediary level is the level of true questions." 15

\section{ii. My Dramatic Works as Viewed by the Philosopher}

Several books and articles have been written on the topic of Marcel's aesthetic work. ${ }^{16}$ The difficulties involved with such an undertaking are by no means meager. Marcel wrote prodigiously on the topic in both his philosophical works and his works of drama criticism. ${ }^{17}$ Further, as Marcel

15 Schilpp, Ricoeur, "Gabriel Marcel and Phenomenology," 481; cf., "la révélation du chef-d'euvre ne se laisse en effet aucunement réduire à un état de simple satisfaction ressentie. Ce niveau intermédiaire est celui des vraies questions" [Ricoeur, "Marcel et la phénoménologie," Entretiens, 63].

16 Katharine Rose Hanley, Dramatic Approaches to Creative Fidelity, a study in the theatre and philosophy of Gabriel Marcel (18891973) (New York: University Press of America, 1987), cf, Francis J. Lascoe, The Existentialist Drama of Gabriel Marcel, (Hartford: McAuley Institute of Religious Studies, 1974), n.b., the introduction to this work, written by Marcel, is particularly informative; Joseph Chenu, Le Theatre de Gabriel Marcel et sa Signification metaphysique (Paris: Aubier, 1948); Guillemine Lacoste, "The Notion of participation in the early Drama and the early Journals of Gabriel Marcel", Philosophy Today, Volume XIX, no. 1/4, Spring 1975, 50-60; Gabriel Marcel, Presence de Gabriel Marcel, Cahier 2-3, L'esthétique musicale de Gabriel Marcel, Paris: Aubier, 1990.

17 cf., Gabriel Marcel, Presence de Gabriel Marcel, cahier 2-3, "L'esthétique de Gabriel Marcel," Paris: Aubier, 1990. 
has repeatedly claimed, "there is a strong bond between my philosophical thought and my dramatic work."18 This section will focus on a highly provocative, though little known, work of Marcel. Marcel delivered a lecture at Freiburg in 1959 entitled "My Dramatic Works as Viewed by the Philosopher." 19

Marcel begins his analysis of his own literary work with a question characteristic of his philosophical method. He attempts a "concrete approach" to the philosophical mystery of his own creativity. ${ }^{20}$ He begins by asking, "what constitutes the 'I' when I refer to my work?" Very early in his philosophical endeavors, Marcel came to realize that his "personal concrete situation" would, of necessity, have an effect on his thought. In other words, "the substantial being I call my 'I' cannot rightly be separated from the empirical data, for these are simply the data of my own existential becoming! It would be wrong to assert categorically that empirical data exists separately from the determination of thinking." 21 This emphasis provides the basis for understanding his dramatic art. Persons must be represented in "definite situations," lest one be left with nothing but "tainted abstractions."

18 Gabriel Marcel, "A letter to Donald M. MacKinnon", Schilpp, 581.

19 Gabriel Marcel, "My Dramatic Works as Viewed by the Philosopher", Searchings, translated under the direction of Wolfgang Ruf (New York: Newman Press, 1967), 93-118, n.b., this constitutes Marcel's most explicit analysis of the connection between his philosophy and dramatic work.

20 n.b., it is in just this aspect that Marcel has been curiously described as a Christian Socratic (Joseph Chenu) or, even, a 'radical empiricist' (Charles Hartshrone).

21 Marcel, Searchings, 95. 
The impetus which motivates Marcel's philosophical thought attempts a penetration of the deceptive veils of abstraction, formalism, idealism and neologism. This impetus is, likewise, the cornerstone of his literary theory. ${ }^{22}$ Simply put, the question of Being is never merely abstract or ideal in nature. Mystery in no way implies other-worldliness, spiritualism, dualism or idealism. Rather, an approach to mystery is an approach to a mystery which is embodied and incarnate. For Marcel, the "thing" and the "thing thought about" exist in a phenomenological unity. They can only be wrenched apart by an unwarranted, and ultimately vicious, abstraction. As such, one could say that Marcel writes plays for the same reason that he writes philosophy, to approach the mystery of Being.

Marcel understands his philosophy to be incomplete without the insight of his plays. Rationality is not complete without the tempering influence of empirical data. For him, literature is not an aid to philosophy or an instrument of a downtrodden and marginalized social group or a vent for repressed impulses, though of course literature can be reductively employed for any of these purposes. At its deepest level, literature presents a way of "knowing reality" which is unique and irreducible to any other method. Literature is itself a discourse with its own rationality and truth claims which are substantially different from those of philosophy. Art may compliment philosophy but it is not a watered-down version of philosophy.

Marcel claims that to understand his work, one must understand something of his life. His mother died when he

22 Marcel, Philosophy of Existentialism, trans by Manya Harari, (New York: Citadel, 1984), "An essay in Autobiography", 117-127, this passage offers an excellent summary of this development in Marcel's thought. 
was young. This event had a profound effect on his life. Hereafter, he was raised by a very strict and demanding aunt who seemed to live vicariously through young Gabriel. Since Marcel had no brothers or sisters, he felt himself rather "too much in the limelight; I needed a little shade if I was going to exist peacefully...I had to populate my loneliness with all sorts of imaginary beings. And these became the real milieu of my early life, the atmosphere that eventually gave birth to my dramatic characters." ${ }^{23}$ This concept of a "shade" is an interesting one. He implies that literary creativity is not so much a gift of angelic proportions (the inspired "genius" of Romanticism) or a manic invasion of the muse (the Platonic daemon). Rather, it is more like the wrestling of Jacob with the angel. It is a struggle within incarnation and corporeality. Hence, creativity is an expression of an underlying unity. It is the unity of subject and object which is understood dynamically in the recognition of the "I."

The artist does not create because creativity is dropped into his or her lap but because he or she is wrestling with reality and seeking meaning. The unconcealment of meaning is not realized by fleeing the world but by entering more deeply into it. Literary work is an attempt to enter deeply into Being, while always recognizing that Being can be found only in beings. Therefore, and here is the truly radical aspect of Marcel's literary theory, he would contend that "my literary work portrays real existence more powerfully than any of my philosophical writings ever could." ${ }^{24}$ By way of example, he points out the ambiguous essence of one of his heroines. Such ambiguity points to a higher truth but that truth cannot be expressed in strictly rational terms. Rather, it requires, for its expression, a concrete approach which is grounded in human

Marcel, Searchings, 97.

${ }^{24}$ Marcel, Searchings, 102. 
experience. Truth is not a mere problem to be analyzed and dissected by logicians. Truth is a thing of mystery, nonobjectifiable, unverifiable and for-someone. Precisely, literature has the competence to express that painful ambiguity in a way that is impossible for philosophical thought. In 1937, Marcel wrote a short article entitled "Spiritual Values in French Contemporary Theatre." Therein he makes the point of fiction's relevance with force:

The characters brought forth by the playwright are multiple; each says 'I; it is therefore necessary, through an effort directed against our natural inclination, that the playwright find the means to place himself simultaneously at the deepest level possible in each one, that he adopt their ways of being, of understanding, of appreciating which oppose each other in practice and may even reveal themselves to be forever incompatible. In real life, I should probably be forced to side with one of these characters against the other or to become disinterested in them. In the privileged domain of drama, I am spared this choice...For several moments it will be possible for me not only to take in existence more widely, but also to reach a higher justice that resembles charity, promises it, allowing me both to be all the antagonists at once as well as to understand and rise above them, without necessarily being able to work out a formula that can be stated, allowing this 
act to be expressed in an intelligible synthesis. ${ }^{25}$

There crucial aspect of this analysis is that literature allows one "to take in existence more widely." Art has an amplificatory effect. Art makes possible the assimilation of broader meanings for the audience, actually, one could claim that they allow for a "play" of meanings or "open a space" of meaning. For Marcel, the "intelligible synthesis" of literary narrative is a result of the fact that the audience and the playwright are able to be all the characters at once, as well as to understand and rise above them. Rule of Metaphor makes this very point that metaphor has an unique philosophical function. Metaphor levels us up to a higher plane of meaning. This idea is very close to Marcel's idea of mystery, and Ricoeur's debt to his teacher Marcel is obvious at this point.

Drama presents truth in an existential fullness, within the concrete situation and does not reduce the human reality to sterile abstractions or prosaic schematics. By extension of this idea as to the irreducibility of dramatic works, Marcel contends, "nothing is more important for dramatic work than the absence of a definite purpose. A dramatic work must never be written to support an idea the author wants to hammer into the heads of his audience. The dignity of a dramatic work can only be preserved if the author's rejection of any outside determination of its actual objective is absolute and unconditional. ${ }^{26}$

One could ask if Marcel is faithful to his own dictum in this regard. Which is to say, one perceives an apologetic

25 From the forward to Marcel's Le Monde casse, quoted by Gaston Fessard in "Theatre et mystere," the preface to Marcel's play $L a$ Soif (Paris: Desclee de Brouwer, 1938).

${ }^{26}$ Marcel, Searchings, 106. 
tone and extra-literary motives in his plays. They often read like thinly disguised philosophy. Regardless, one must ask if it is not a violation of the integrity of a creative work to present a Marxist novel or a Catholic novel or a feminist novel or a reactionary novel. Which is to say, there must be a sense in which a literary work is not merely a transcription of some doctrinal or philosophical position into aesthetic images. Such a mere transcription is unworthy of the name of literature.

This needs more clarification but it seems that literature which is mere apologetics or moralizing is lacking something which is of the essence of literature. Or to employ Kantian language, the aesthetic interest betrays itself when it allows itself to be determined by a theoretical or practical demand of pure reason.

In point of fact, many great works of literature do indeed seem to have a definite purpose and, even, are apologetic in tone. Surely, one does not deny that the mystical love poetry of John of the Cross is great literature because it is so unabashedly Christian, or that the plays of Tennessee Williams are not great drama due to the fact that they deal so much with his desire to come to grips with his homosexuality, or that the poetry of Walt Whitman is inferior because it enshrined his obviously political opinions about the state of his country.

Marcel's meaning is clarified by way of an example, The Ring Cycle of Richard Wagner was written with obvious, overt political and nationalistic intentions. It is a glorification of the German Spirit and enshrines Wagner's personal bigotries. Since the time of its composition, it has been employed as Nazi propaganda (it was the most beloved music of Hitler himself) and, more unconventionally, it has been interpreted as an unconscious Communist apology (George Bernard Shaw). Nonetheless, the point must be made that Wagner's art has little to do with Wagner's nationalism or his 
penchant for propaganda. Were Wagner an inferior artist, as Hitler himself was with his unimpressive landscape drawings, no amount of nationalistic piety or apologetic intent could have made "bad" music, "good." Rather, Wagner's music possesses a depth and aesthetic integrity which is not dependent on his extra-aesthetic intentions. It is precisely the error of the Romantics to posit meaning as contingent on the intention or the genius of the artist. ${ }^{27}$ Further, it would seem that recovering the "original intention" of the artist is a futile and impossible task in any event. Art, be it literature or music, is an autonomous discourse. If Wagner's music endures as music, it is not because of what Wagner was trying to express. Instead, it endures because it expresses some truth which is aesthetic and not formal in character. It has more to do with how it is said than what is said.

The existential aspect of existential literature, for Marcel, is traced to the concept of paradox as it is found in Kierkegaard. "Every existential philosopher is bound to acknowledge at least some insoluble paradoxes." ${ }^{28}$ One can take, for example, the reality of grief. Let us propose the case of a man who has lost the only woman he has ever loved. The Irish poet F. O'Connor presents a striking image of his grief on the death of his wife: 0

I lie stretched on your grave and will lie here forever.

If your hands were in mine, I'd be sure that we'd not sever.

My apple tree, my brightness, it's time we were together

$27 c f$., The critique of the Romantic notion of genius as found in the first chapters of Hans- Georg Gadamer's Truth and Method, trans by Joel Weinsheimer, New York: Crossroad, 1991), 3-100.

28 Marcel, Searchings, 111. 
for I smell of the earth and am worn by the weather.

While my family thinks that I'm safe in my bed, from night until morning I lie stretched at your head.

Calling out to the air, with tears hot and wild, my grief for the girl that I loved as a child.

Do you remember, the night we were lost in the shade of the blackthorn and the chill of the frost?

The priests and the friars approach me with dread because I still love you, my love, and your dead.

I still would be your shelter through rain and through storm and with you in a cold grave, I cannot sleep warm...

There is an aspect of this man's grief at the loss his wife which is more than inconsolable. The "priests and the friars" have no answer for him by offering theological legitimizations or religious explanations of death. In actuality, such explanations do worse damage than merely failing to explain; they violate and distort the truth that lies at the heart of grief. The reality presented in this deep sorrow is profoundly mysterious and cannot be understood by analysis and rationalization. The faithful and the priests do not surpass the sufferer in any way: "The only one who can be of assistance at such moments is someone who has been dragged equally deep through the abyss we call pain. Only then can he reach the one who is suffering and share his experience." 29 The value of literature for this process of understanding and sublimating is inestimable.

29 Marcel, Searchings, 111. 
Marcel the "author" is, for Marcel the "philosopher," an essential, compensatory force. Professors of philosophy are given to a kind of schematizing with which Marcel has little patience. When Marcel was a school boy, he memorized a phrase of Terence: Nihil humani a mei alienum puto (I believe that nothing human is alien to me). The schemes of philosophical thought are not absolutely adequate for apprehending human reality. Through drama, a mysterious clarity arises. It is a clarity which pertains to people and not things. For example, "a mysterious hidden bond exists between love and truth, expressed more often by allusion than by clear statement. ${ }^{130}$ It is the domain of literature to expose such a bond in terms of the context of the concrete situation. Philosophy which does not, at least, admit the existence of this domain, the domain of that which lies beyond the strictly rational, is woefully inadequate to grasp the human reality. To put the matter simply, thought is grounded in that which transcends it, and the thinkable is framed by the unthinkable. The value of art for this process has been firmly established in the Western tradition at least since the time of the Critique of Judgment.

Music, drama and art are ultimately appeals and "creative testimonials." 31 They are appeals to the soul by being-itself. This call and response is the very constitution of the human soul This power of creative fidelity is concentrated in the forms of artistic expression. By entering into these sorts of aesthetic affirmations, our assurance as to Being is strengthened and refusal is rejected: "or to formulate this in a

30 Marcel, Searchings, 117.

31 Gabriel Marcel, Creative Fidelity, trans by Robert Rosthal, (New York: Crossroad, 1982) 10; cf., "d'attestation créatrice" [Gabriel Marcel, De refus a l'incocation, (Paris: Gallimard, 1956), 16]. 
more profound way, the denial of the more than human by the less than human" is overcome." 32

In aesthetic experience, "the human person is recalled into the presence of mystery, the mystery which is the foundation of his very being, and apart from which he is nothingness: the grand mystery of religion, art and metaphysic."33 Mystery is not merely a technical term that Marcel trots out for show. Rather, the core of his thought involves a concrete approach to the ontological mystery. Aesthetic experience is one of his favorite modes of approaching that mystery.

St. John Vianney College Seminary

REV. DR. ROBERT W. VALLEE

32 Marcel, Creative Fidelity, 10; cf., “c'est-à-dire, plus profondément, du plus qu'humain par ler moins qu'humain" [Marcel, De refus, 17].

33 Marcel, Being and Having, 174; cf., "Encore faut-il que ces activités, ces fonctions autonomes trouvent leur contrepartie dans les activités centrales par lesquelles l'homme se remet lui-même en présence du mystère qui le fonde et hors duquel il n'est que néant: la religion, l'art, la métaphysique" [Marcel, Être et avoir, 124]. 